\title{
JNPH
}

Volume 6 No. 2 (Oktober 2018)

(C) The Author(s) 2018

\section{HUBUNGAN POLA MAKAN DENGAN STATUS GIZI PENDERITA TB PARU DI WILAYAH PUSKESMAS SUKA MAKMUR DAN PUSKESMAS SEBLAT BENGKULU UTARA TAHUN 2018}

\author{
RELATIONSHIP DIET WITH NUTRITIONAL STATUS OF PULMONARY TB \\ PATIENTS IN THE AREA OF PUSKESMAS SUKA MAKMUR AND SEBLAT \\ BENGKULU UTARA PUBLIC HEALTH CENTER IN 2018
}

\author{
${ }^{1}$ ELSI RAHMADANI, ${ }^{2}$ AHMAD RIADIN NASUHA, ${ }^{3}$ MIDIAWATI \\ PROGRAM STUDI ILMU KEPERAWATAN FAKULTAS ILMU KESEHATAN \\ UNIVERSITAS DEHASEN BENGKULU \\ JL. MERAPI RAYA NO.42 KEBUN TEBENG BENGKULU \\ E-mail : elsirahmadani@yahoo.co.id, midiawati@gmail.com Hp. 085267708487
}

\begin{abstract}
ABSTRAK
Tuberkulosis adalah penyakit infeksi yang disebabkan oleh infeksi bakteri Mycobacterium Tubercolosis dan masih menjadi masalah kesehatan masyarakat di mana ada satu juta orang meninggal karena TB. Salah satu efek yang terjadi pada pasien TB Paru adalah status gizi tidak normal. Tujuan penelitian ini adalah untuk mengetahui hubungan pola makan dengan status gizi penderita Tuberkulosis Paru di Puskesmas Suka Makmur dan Puskesmas Seblat Kabupaten Bengkulu Utara pada tahun 2018. Metode yang digunakan dalam penelitian ini adalah metode analitik, menggunakan rancangan cross sectional. Populasi dalam penelitian ini adalah 43 penderita TB Paru di Puskesmas Suka Makmur dan di Puskesmas Seblat tahun 2017 sebanyak 43 sampel data yang diambil dengan total sampling. Analisis data yang digunakan dalam penelitian ini menggunakan univariat dan bivariat menggunakan analisis chi square. Hasil analisis univariat menunjukkan bahwa hampir separuh responden $(51,2 \%)$ memiliki pola makan buruk dan separuh responden (55,8\%) memiliki status gizi normal, sedangkan menurut analisis chi-square menunjukkan bahwa $\mathrm{p}=0,002$ lebih kecil dari alpha 0, 05. Artinya ada hubungan antara pola makan dengan status gizi TB paru. Diharapkan kepada semua institusi kesehatan masyarakat dapat meningkatkan observasi dan penyuluhan untuk meningkatkan pengetahuan tentang TB Paru terutama pentingnya pola makan yang baik melalui peningkatan konseling gizi.
\end{abstract}

Kata Kunci : Tuberkulosis, TB Paru, Gizi

\begin{abstract}
Tuberculosis is an infectious disease which cause by Mycobacterium Tubercolosis bacteria infection and still becoming public health problem where there are a million people died because of TB. One effect which occurred on Pulmonary TB patient is abnormal nutritional status. The purpose of this research is to find out Correlation between eating pattern with nutrition status of Pulmonary Tuberculosis patient at Suka Makmur Public Health and Seblat Public Health North Bengkulu in 2018. The method used in this research is analytic method,
\end{abstract}


used cross sectional design. Population in this research is 43 Pulmonary TB patients at SukaMakmur public health and seblat public health in 2017 an 43 samples data are taken with total sampling. Data analysis which used in this research is using univariate and bivariate using chi square analysis. Univariate analysis result shows that almost half of respondents $(51,2 \%)$ have bad eating pattern and half respondents $(55,8 \%)$ have normal nutritional status, while according to chi-square analysis shows that $\mathrm{p}=0,002$ smaller than alpha 0,05 . It means there is a correlation between eating pattern with nutritional status of pulmonary TB. It is expected that to all public health institution can improe observation and counseling to improve the knowledge about Pulmonary TB especially the important of good eating pattern thru improvement of nutrition counseling.

\section{Keywords: Tuberculosis, Pulmonary TB, Nutrition}

\section{PENDAHULUAN}

Penyakit Tuberkulosis

(TB)

merupakan penyakit menular yang masih menjadi masalah kesehatan masyarakat, dimana menyebabkan jutaan orang meninggal setiap tahun akibat penyakit TB. Menurut badan kesehatan dunia World Health Organization (WHO) Tuberkulosis (TB) adalah salah satu dari 10 penyebab kematian terbesar di dunia. Selain itu juga TB paru merupakan salah satu pembunuh utama pada penderita human immunodeficiency virus (HIV). (WHO, 2018).

Pada tahun 2016, 10,4 juta orang jatuh sakit dengan TB, dan 1,7 juta meninggal karena penyakit (termasuk 0,4 juta di antara orang dengan HIV). Lebih dari 95\% kematian TB terjadi di negara berpenghasilan rendah dan menengah. Pada tahun 2016, juga diperkirakan 1 juta anak-anak mengalami TB dan 250.000 anak meninggal karena TB (termasuk anak-anak dengan HIV terkait TB). TB juga merupakan pembunuh utama orang HIV-positif: pada tahun 2016, 40\% kematian HIV disebabkan oleh TB (WHO, 2018).

Badan kesehatan dunia WHO juga menyebutkan bahwa Multi Drug Resistant TB (MDR-TB) tetap merupakan krisis kesehatan masyarakat dan ancaman keamanan kesehatan. WHO memperkirakan bahwa ada 600.000 kasus baru dengan resistansi terhadap rifampicin obat lini pertama yang paling efektif, dimana 490.000 memiliki MDR TB. Secara global, kejadian TB menurun sekitar $2 \%$ per tahun. Ini perlu dipercepat hingga $4-5 \%$ penurunan tahunan untuk mencapai tonggak tahun 2020 dari Strategi TB Akhir (WHO, 2018).

Indonesia merupakan negara dengan jumlah kasus baru (TB paru), terbanyak kedua di dunia setelah India. Sebesar $60 \%$ kasus baru terjadi di 6 negara yaitu India, Indonesia, China, Nigeria, Pakistan dan Afrika Selatan. Kematian akibat tuberkulosis diperkirakan sebanyak 1,4 juta kematian ditambah 0,4 juta kematian akibat tuberkulosis pada orang dengan HIV (Kemenkes RI, 2017).

Pada tahun 2016 ditemukan jumlah kasus tuberkulosis sebanyak 351.893 kasus, meningkat bila dibandingkan semua kasus tuberkulosis yang ditemukan pada tahun 2015 yang sebesar 330.729 kasus. Jumlah kasus tertinggi yang dilaporkan terdapat di provinsi dengan jumlah penduduk yang besar yaitu Jawa Barat, Jawa Timur dan Jawa Tengah. Kasus tuberkulosis di tiga provinsi tersebut sebesar $44 \%$ dari jumlah seluruh kasus baru di Indonesia. Angka notifikasi kasus tuberkulosis pada tahun 2016 sebesar 136 per 100.000 penduduk meningkat dibandingkan dengan tahun 2015 sebesar 130 per 100.000 penduduk (Kemenkes RI, 2017).

Salah satu upaya untuk mengendalikan TB yaitu dengan pengobatan. Indikator yang digunakan sebagai evaluasi pengobatan yaitu angka keberhasilan pengobatan (success rate). Angka keberhasilan pengobatan ini dibentuk dari angka kesembuhan (cure rate) dan angka pengobatan lengkap. Kementerian Kesehatan menetapkan target Renstra 
minimal $\geq 90 \%$ untuk angka keberhasilan pengobatan pada tahun 2016. Namun pada pada tahun 2016 angka keberhasilan pengobatan TB paru di Indonesia hanya sebesar $85,1 \%$ yang berarti tidak memenuhi target Renstra (Kemenkes RI 2016).

Penderita TB paru sangat rentan mengalami resiko gangguan status gizi yang tidak normal hal ini dibuktikan oleh hasil penelitian Salsabela (2016), di Rumah Sakit Umum Pusat Hasan Sadikin Bandung menunjukkan bahwa $37(35 \%)$ pasien memiliki IMT Underweight $(<18,5 \mathrm{~kg} / \mathrm{m} 2)$, $44(41 \%)$ pasien memiliki IMT Healthy weight $(18,5-22.9 \mathrm{~kg} / \mathrm{m} 2), 13$ (12) pasien memiliki IMT Overweight $(23-24,9 \mathrm{~kg} / \mathrm{m} 2)$ dan 13 (12) pasien memiliki IMT Obese Class I (25-29,9 kg/m2) (Salsabela, 2016).

Berdasarkan latar belakang yang di uraikan diatas peneliti berkeinginan melakukan penelitian dengan judul "Hubungan pola makan dengan status gizi penderita TB paru di wilayah Puskesmas Suka Makmur dan Puskesmas Seblat Bengkulu Utara tahun 2018".

\section{METODE PENELITIAN}

Jenis penelitian ini adalah penelitian secara analitik dengan menggunakan desain cross-sectional. Populasi dalam penelitian ini adalah seluruh pasien TB paru yang berada di wilayah puskesmas Suka Makmur Bengkulu Utara tahun 2017 sebanyak 22 orang dan puskesmas Seblat Bengkulu Utara tahun 2017 sebanyak 21 orang, dengan cara pengambilan sampel dalam penelitian ini dengan menggunakan teknik total sampling yaitu teknik subyektif dengan mengumpulkan data dimana keseluruhan populasi dijadikan sampel. sampel dalam penelitian adalah seluruh penderita TB paru sebanyak 43 responden.Dalam pengambilan sampel ini didasari dengan kriteria inklusi yaitu: usia responden 17-50 tahun, bersedia menjadi responden, tidak cacat, pasien yang dalam masa pemulihan, dapat membaca dan menulis. Data yang diperoleh selanjutnya, diolah dan dianalisis dengan menggunakan analisis univariat dan analisis bivariat.

\section{HASIL PENELITIAN}

1. Analisis Univariat.

Tabel 1 Distribusi Frekuensi Pola Makan Penderita TB paru di wilayah Puskesmas Suka Makmur dan Puskesmas Seblat Bengkulu Utara tahun 2018

\begin{tabular}{ccc}
\hline Pola Makan & Frekuensi & $\begin{array}{c}\text { Persentase } \\
(\%)\end{array}$ \\
\hline Tidak Baik & 22 & 51,2 \\
\hline Baik & 21 & 48,8 \\
\hline Total & 43 & 100 \\
\hline
\end{tabular}

Berdasarkan tabel 1 diketahui bahwa lebih setengah responden $(51,2 \%)$, mempunyai pola makan tidak baik dan hampir sebagian responden (48,8\%), mempunyai pola makan yang baik.

Tabel 2 Distribusi Frekuensi Status Gizi Penderita TB Paru di Wilayah Puskesmas Suka Makmur dan Puskesmas Seblat Bengkulu Utara tahun 2018

\begin{tabular}{ccc}
\hline Status Gizi & Frekuensi & $\begin{array}{c}\text { Persentase } \\
(\%)\end{array}$ \\
\hline Kurus & 15 & 34,9 \\
\hline Normal & 24 & 55,8 \\
\hline Gemuk & 4 & 9,3 \\
\hline Total & 43 & 100 \\
\hline
\end{tabular}

Berdasarkan tabel 2 diketahui bahwa hampir sebagian responden (34,9\%), mempunyai status gizi kurus, lebih dari setengah responden $(55,8 \%)$, mempunyai status gizi normal sedangkan sebagian kecil responden mempunyai $(9,3 \%)$, status gizi lebih.

\section{Analisis Bivariat.}

Anailis bivariat pada penelitian ini untuk mengetahui hubungan pola makan dengan status gizi penderita TB paru di wilayah Puskesmas Suka Makmur dan 
Puskesmas Seblat Bengkulu Utara tahun 2018 yang dapat dilihat pada tabel berikut:

Tabel 3 Hubungan Pola Makan dengan Status Gizi Penderita TB Paru di Wilayah Puskesmas Suka Makmur dan Puskesmas Seblat Bengkulu Utara tahun 2018

\begin{tabular}{cccccccccc}
\hline Variabel & \multicolumn{4}{c}{ Status Gizi } & & & & $p$ \\
& & Kurus & Normal & Gemuk & Total & Value \\
\cline { 2 - 8 } $\begin{array}{c}\text { Pola } \\
\text { Makan }\end{array}$ & $\mathrm{f}$ & $\%$ & $\mathrm{f}$ & $\%$ & $\mathrm{f}$ & $\%$ & $\mathrm{f}$ & $\%$ & \\
\hline $\begin{array}{c}\text { Tidak } \\
\text { Baik }\end{array}$ & 13 & 59,1 & 7 & 31,8 & 2 & 9,1 & 22 & 100 & 0,002 \\
\hline Baik & 2 & 9,5 & 17 & 81,0 & 2 & 9,5 & 21 & 100 & \\
\hline
\end{tabular}

Berdasarkan tabel 3 diketahui bahwa dari 22 responden yang mempunyai pola makan tidak baik terdapat $13 \quad(59,1 \%)$, responden yang mempunyai status gizi kurus, $7(31,8 \%)$ responden mempunyai status gizi normal dan 9,1 responden mempunyai status gizi lebih. Sedangkan dari 21 responden yang mempunyai pola makan baik terdapat 2 $(9,5 \%)$, responden yang mempunyai mempunyai status gizi kurus, $17(81,0 \%)$, mempunyai status gizi normal dan $2(9,5 \%)$, responden mempunyai status gizi lebih. Hasil analisis chi-square menunjukkan bahwa nilai $p=0,002$ lebih kecil dari nilai alpha 0,05 artinya ada hubungan pola makan dengan status gizi penderita TB paru di wilayah Puskesmas Suka Makmur dan Puskesmas Seblat Bengkulu Utara tahun 2018.

\section{PEMBAHASAN}

Hasil penelitian ini diketahui lebih setengah dari responden $(51,2 \%)$, mempunyai pola makan tidak baik dan hampir sbagian dari responden $(48,8 \%)$, mempunyai pola makan baik. Hasil penelitian ini menggambarkan bahwa pola makan penderita TB paru masih dalam kategori kurang baik, keadaan ini sangat disayangkan karena dengan pola makan yang tidak baik ini dapat mengakibatkan terjadinya gangguan status gizi yang dapat mengakibatkan bertambah parahnya penyakit (Hizira, 2008).
Hasil penelitian Dewi (2016), pada pasien tuberkulosis RSUD Kayen Kabupaten Pati menunjukkan bahwa terdapat perbedaan yang signifikan terhadap berat badan sebelum dan sesudah terapi OAT $(p=0,000)$. Hasil penelitian Pratiwi (2016), Pada Pasien TB MDR Rawat Jalan Di Rsup Sanglah Denpasar menunjukkan bahwa terdapat sebanyak $(66,67 \%)$ pasien dengan efek samping ringan dan sebanyak $(13,33 \%)$ pasien yang mengalami efek samping berat. sebanyak.

Hasil penelitian ini menunjukkan bahwa hampir sebagian responden $(34,9 \%)$, mempunyai status gizi kurus, lebih dari setengah responden $(55,8 \%)$, mempunyai status gizi normal dan sebagian kecil responden mempunyai $(9,3 \%)$, status gizi lebih. Hasil penelitian ini menggambarkan bahwa penderita cenderung mempunyai status gizi normal, hal ini dapat terjadi karena adanya pola makan yang baik dari penderita TB paru dalam memenuhi kebutuhan nutrisinya. Selain itu masih banyakya juga penderita TB paru yang mengalami gizi kurus ini dapat terjadi karena adanya keparahan penyakit maupun adanya perilaku yang tidak baik dari penderita TB dalam pemenuhan nutrisi bagi kebutuhan tubuhnya (Triwibowo, 2015).

Hasil penelitian ini sesuai dengan pendapat Dewi, (2012), yang menyatakan bahwa status gizi sangat berpengaruh terhadap sistem ketahanan tubuh agar tidak mudah terinfeksi. Tuberkulosis merupakan penyakit infeksi menular langsung yang disebabkan kuman Mycobacterium tuberculosis. Hubungan antara status gizi kurang dengan penyakit infeksi merupakan hubungan timbal balik (sebab-akibat), sehingga keadaan gizi yang jelek dapat mempermudah terkena suatu infeksi (Dewi, 2012).

Hasil penelitian menunjukkan bahwa ada hubungan pola makan dengan status gizi penderita TB paru di wilayah Puskesmas Suka Makmur dan Puskesmas Seblat Bengkulu Utara tahun $2018(p=0,002)$. Hasil penelitian ini menunjukkan bahwa pola makan pada penderita TB paru merupakan 
salah satu faktor yang dapat meningkatkan resiko terjadinya gangguan gizi.

Hasil penelitian ini sesuai dengan pendapat Adriani dan Wirjatmadi, (2014), yang menyatakan bahwa keadaan kesehatan gizi tergantung dari tingkat konsumsi. Tingkat komsumsi yang ditentukan kualitas serta kuantitas hidangan. Kualitas hidangan menunjukan adanya semua zat gizi yang diperlukan tubuh didalam susunan hidangan dan perbandingannya yang satu terhadap yang lain. Kuantitas menunjukan kuantum masingmasing zat gizi terhadap kebutuhan tubuh. Kalau susunan hidangan memenuhi kebutuhan tubuh, baik dari sudut kualitas maupun kuantitasnya maka tubuh akan mendapatkan kondisi kehatan gizi yang sebaik-baiknya.

Hasil penelitian ini sesuai dengan pendapat Salsabela, (2016), yang menyatakan bahwa pola makan mempunyai pengaruh yang besar terhadap status gizi seseorang terlebih pada seseorang yang menderita penyakit infeksi seperti penderita TB paru yang harus menjalani pengobatan jangka panjang dan pengobatan tersebut dapat menyebabkan beberapa efeksamping yang dapat mempengaruhi pola makan dan dapat berkibat kepada stasus gizi seorang penderita TB paru tersebut (Salsabela, 2016).

\section{KESIMPULAN}

1. Lebih setengah responden $(51,2 \%)$, mempunyai pola makan tidak baik

2. Lebih dari setengah responden $(55,8 \%)$, mempunyai status gizi normal

3. Ada hubungan pola makan dengan status gizi penderita TB paru di wilayah Puskesmas Suka Makmur dan Puskesmas Seblat Bengkulu Utara tahun 2018 $(p=0,002)$

\section{SARAN}

1. Kepada peneliti selanjutnya

Kepada peneliti selanjutnya diharapkan agar berupaya lebih mengembangkan dan memperdalam bahasan tentang faktor yang mempengaruhi terjadinya penurunan status gizi pada penderita TB paru, seperti tingkat keparahan penyakit, lama menderita TB paru, maupun faktor status gizi sebelumnya dengan menggunakan desain penelitian yang berbeda seperti penelitian dengan studi case control ataupun kohort sehingga didapat hasil yang lebih memuaskan.

2. Institusi Puskesmas Puskesmas

$\begin{array}{rcr}\text { Kepada } & \text { pihak } & \text { instituti } \\ \text { Puskesmas } & \text { diharapkan } & \text { dapat }\end{array}$ meningkatkan program pemantauan maupun penyuluhan kesehatan dan konseling untuk meningkatkan pengetahuan penyakit tuberkulosis paru terutama mengenai pentingnya pola makan yang baik melalui peningkatan peran penyuluhan gizi oleh petugas kesehatan (petugas gizi, kader) agar penderita TB Paru lebih meningkatkan tingkat konsumsi energi dan protein sesuai dengan kebutuhan baik dari segi kualitas maupun kuantitas dan diharapkan pada pihak puskesmas dapat Program pemberian makanan tambahan (PMT) bagi penderita TB Paru untuk peningkatan status gizi dan mempercepat penyembuhan serta mengurangi risiko penularan TB Paru terhadap masyarakat lainya.

3. Bagi Responden.

Bagi responden diharapkan dapat meningkatkan asupan gizi dan memperbaiki pola makan yang sehat sehingga dapat terhindar dari beberapa penyakit yang dapat meningkatkan kesehatan dan mengurangi efek ditimbulkan dari keadaan status gizi yang tidak adekuat selain itu diharapakan dapat melakukan upayaupaya peningkatan kesehatan dengan prilaku yang baik seperti perilaku hidup bersih dan sehat. 


\section{DAFTAR PUSTAKA}

Adriani dan Wirjatmadi. 2012. Peranan Gizi dalam Siklus Kehidupan. Kencana Prenadamedia Group: Jakarta

Hidayat. 2012. Metode Penelitian Teknik Analisis Data, Salemba Medika: Jakarta.

Handayani. 2012. Gambaran Pola Makan Suku Melayu Dan Suku Jawa Di Desa Selemak Kecamatan Hamparan Perak Kabupaten Deli Serdang. Skripsi. Fakultas Kesehatan Masyarakat Universitas Sumatera Utara. Medan.

Hizira. 2008. Hubungan Pola Konsumsi Dengan Status Gizi Penderita Tb Di Wilayah Kerja Puskesmas Polombangkeng Utara Kabupaten Takalar. Jurusan Gizi Kesehatan Masyarakat Fakultas Kesehatan Masyarakat Universitas Hasanuddin Makassar

Kemenkes RI. 2017.Profil Kesehatan Indonesia 2016. Kementrian Kesehatan Republik Indonesia: Jakarta.

Notoatmodjo. 2010. Metodologi Penelitian Kesehatan. PT Rineka Cipta: Jakarta.

Salsabela. 2016. Gambaran Status Nutrisi pada Pasien Tuberkulosis di Rumah Sakit Umum Pusat Hasan Sadikin Bandung. JSK, Volume 2 Nomor 2 Desember Tahun 2016

WHO. 2018. Tuberculosis. diakses dari http://www.who.int/mediacentre/factsheet s/fs104/en/ pada tanggal 27 maret 2018 